\title{
Milligram per Kilogram
}

National Cancer Institute

\section{Source}

National Cancer Institute. Milligram per Kilogram. NCI Thesaurus. Code C67401.

A unit of a mass fraction expressed as a number of milligrams of substance per kilogram

of mixture. The unit is also used as a dose calculation unit. 